\title{
Fine Structural and Cytochemical Aspects of Granu- loma Formation Derived from Kupffer Cells in Mice Injected with Latex Particles*
}

\author{
Keisuke Yamashita, Hisao Fujita and Seiichi Kawamata \\ Department of Anatomy (Prof. H. Fujita), Osaka University Medical School, Osaka, Japan
}

Received May 4, 1985

Summary. The fate of Kupffer cells in mice for 3 days following injection with polystyrene latex particles $(0.2$ and $2.0 \mu \mathrm{m}$ in diameter) was studied by electron microscopy. Kupffer cells took up the latex particles by pinocytosis as well as by phagocytosis. The particles ingested were in contact or fused with lysosomes in the cell. Two days after the final injection, most Kupffer cells were already stuffed with the particles. Within one month, cell clumps or cell aggregates, which could be called granuloma, were formed in the liver connective tissue space, i.e., Disse spaces, interlobular connective tissue spaces and subperitoneal connective tissue spaces. They were mostly composed of cells laden with numerous latex particles. The large granulomas were $80-120 \mu \mathrm{m}$ in diameter. In each granuloma, endogenous peroxidase was localized in the cisternae of the nuclear envelope and of the rough endoplasmic reticulum of most cells, and in the cytoplasmic granules of some other cells. The former is known to be a Kupffer cell, and the latter, a monocyte. The granuloma further contained a few intermediate cells, showing peroxidase activity in the cisternae of the nuclear envelope and of the rough endoplasmic reticulum, and also in the cytoplasmic granules, phagocytic cells without peroxidase activity, granulocytes, and plasma cells. Hepatic sinusoidal endothelial cells, attenuated in shape, also took up latex particles of a $0.2 \mu \mathrm{m}$ diameter and rarely with a $2.0 \mu \mathrm{m}$ diameter in their cytoplasm. Some Kupffer cells in the granuloma filled with numerous latex particles were labeled with ${ }^{3} \mathrm{H}-$ thymidine $(2.5 \mathrm{mCi}$ in total dose) after subcutaneous injection ten times for $80 \mathrm{hr}$. In the animals 8 months after the injection of the latex particles, numerous large granulomas were distributed throughout the liver in the interlobular or subperitoneal connective tissue space. The formation of the granuloma of Kupffer cells is considered to play a great role in the disposing of foreign materials from the functional liver parenchymatous tissue.

The origin, morphology, and function of the Kupffer cell have been the subjects of numerous recent studies. In a previous paper (FuJITA et al., 1983), it has been reported that Kupffer cells in mice intravenously given Indian ink gathered in the liver connective tissue, and formed multinucleate foreign body giant cells. The present paper deals with the reaction of Kupffer cells and endothelial cells after injection of latex beads particles, and the granulomatous formation of the Kupffer cells in the connective tissue space. The origin and the fate of the Kupffer cells, and the biological significance of the granulomatous formation are discussed from their fine structural as well as cytochemical aspects.

\footnotetext{
*This study was supported by grants from the Japanese Ministry of Education, Science, and Culture.
} 


\section{MATERIALS AND METHODS}

Thirty male ddY mice, 4 weeks old, were used for this study. They were daily injected intravenouly with $0.6 \mathrm{ml}$ of pelystyrene latex suspension (Nissin EM Co.) consisting of two volumes of suspension of $0.2 \%$ of latex particles $2.0 \mu \mathrm{m}$ in diameter, and one volume of suspension of $0.2 \%$ of the particles $0.2 \mu \mathrm{m}$ in diameter for three days.

Among them, twenty animals were perfused with $2.5 \%$ glutaraldehyde solution buffered at pH 7.4 with $0.1 \mathrm{M}$ Millonig's phosphate, $3 \mathrm{hr}, 2$ and 15 days, and 1, 2, 3, 4, 5, 6 , and 8 months after the last treatment with latex suspension. The livers, immediately removed, were cut into small pieces and immersed in the same fixative for $3 \mathrm{hr}$ at $4^{\circ} \mathrm{C}$. The tissue blocks were postfixed in $1 \% \mathrm{OsO}_{4}$ solution and buffered at pH 7.4 with $0.1 \mathrm{M}$ Millonig's phosphate containing $5 \%$ sucrose for $2 \mathrm{hr}$ at $4^{\circ} \mathrm{C}$. After dehydration with graded concentrations of ethanol, they were embedded in Epon epoxy resin. Sections cut on a Porter-Blum ultramicrotome were doubly stained with uranyl acetate and Millonig's lead and examined in a Hitachi $\mathrm{H}-500$ type electron microscope.

Six animals injected with the latex suspension were fixed by cardiac perfusion with $1.5 \%$ glutaraldehyde solution buffered at $\mathrm{pH} 7.4$ with $0.1 \mathrm{M}$ cacodylate buffer. The liver tissues at $3 \mathrm{hr}, 2$ days, 3, 4, and 5 months after the last injection of latex particles were immediately removed, and $50 \mu \mathrm{m}$ thick sections were cut on a vibratome and fixed in the same fixative for $30 \mathrm{~min}$. The slices were washed in $0.1 \mathrm{M}$ cacodylate buffer ( $\mathrm{pH} 7.4$ ), containing $5 \%$ sucrose for $12 \mathrm{hr}$ at $4^{\circ} \mathrm{C}$. For peroxidase cytochemistry, some sliced tissues were incubated in the medium by GraHAM and KarnovsKy (1966) containing $0.1 \% 3,3^{\prime}$-diaminobenzidine tetrahydrochloride (DAB) in $0.1 \mathrm{M}$ Tris- $\mathrm{HCl}$ buffer ( $\mathrm{pH} 7.6$ ) and $0.02 \%$ or $0.1 \% \mathrm{H}_{2} \mathrm{O}_{2}$ for $1 \mathrm{hr}$ at $24^{\circ} \mathrm{C}$. For acid phosphatase cytochemistry, the other sliced tissues were incubated in the modified medium by GoMORI (1952) or Novikoff (1963) consisting of $270 \mathrm{mg}$ Na-glycerophosphate, $40 \mathrm{ml}$ of $0.05 \mathrm{M}$ acetate buffer ( $\mathrm{pH} 5.0), 12 \mathrm{ml}$ of $1 \% \mathrm{~Pb}\left(\mathrm{NO}_{3}\right)_{2}, 5 \mathrm{~g}$ sucrose, and $48 \mathrm{ml}$ distilled water for $1.5 \mathrm{hr}$ at $37^{\circ} \mathrm{C}$. Incubated specimens were postfixed in $1 \% \mathrm{OsO}_{4}$ solution buffered at $\mathrm{pH} 7.4$ with $0.1 \mathrm{M}$ Millonig's phosphate for $1-2 \mathrm{hr}$ at $4^{\circ} \mathrm{C}$ followed by dehydration with graded concentrations of ethanol and embedded in Epon epoxy resin. Sections cut on a Porter-Blum ultramicrotome were stained with Millonig's lead and examined in a Hitachi $\mathrm{H}-500$ type electron microscope.

Autoradiography of ${ }^{3} \mathrm{H}$-thymidine was also performed for 4 mice injected with the latex suspension for 3 days. Two animals subcutaneously received ${ }^{3} \mathrm{H}$-thymidine $(20-30$ $\mathrm{Ci} / \mathrm{mmol}$, RCC Amersham) every $8 \mathrm{hr}$ a total of 10 times (2.5 $\mathrm{mCi}$ in total dose). The injection of the radioisotope started on the 2 nd day of the suspension treatment.

In addition, two mice received ${ }^{3} \mathrm{H}$-thymidine every $8 \mathrm{hr}$ a total of 10 times at 2 and 5 months after the injection of latex particles. All the animals were sacrificed $6 \mathrm{hr}$ after the last injection of ${ }^{3} \mathrm{H}$-thymidine. The liver tissues of these animals were fixed, embedded and cut in the same manner as described above. The electron microscopic autoradiography was done by a wire loop method using Ilford L4 emulsion. Following exposure for 6 weeks at $4^{\circ} \mathrm{C}$, the autoradiograms were developed in Microdol X (Kodak) at $20^{\circ} \mathrm{C}$ for 7 min and fixed with $20 \%$ sodium thiosulfate. The grids were stained with Millonig's lead solution and examined with a Hitachi $\mathrm{H}-500$ type electron microscope. Relatively thick sections, dipped into the Ilford L4 emulsion, exposed for 6 weeks, and developed with Microdol $\mathrm{X}$ for $7 \mathrm{~min}$ at $20^{\circ} \mathrm{C}$ were examined by a light microscope. 


\section{OBSERVATIONS}

Two days after the last of the 3-day series of injections of latex particles, numerous beads, both $0.2 \mu \mathrm{m}$ and $2.0 \mu \mathrm{m}$ in diameter were already ingested in almost all the Kupffer cells (Fig. 1). These latex particles tended to accumulate near or in the lysosomal regions in the cytoplasm. Many particles formed clusters enclosed by limiting membrane and were in contact with the lysosomal dense bodies, while some particles were localized within the large electron dense or lucent bodies, $3-13 \mu \mathrm{m}$ in diameter (Fig. 1, inset), which were positive for acid phosphatase activity. The reaction was stronger, especially around the latex particles in these lysosomal bodies though the particles themselves were negative in reaction (Fig. 2). In the animals at 1, 2, 3, 5, and 8 months after the latex injection, the cytoplasm of some Kupffer cells was occupied with large vacuoles stuffed with a great number of latex particles. Most of these vacuoles were positive for acid phosphatase.

Kupffer cells storing numerous latex particles were localized singly or in small

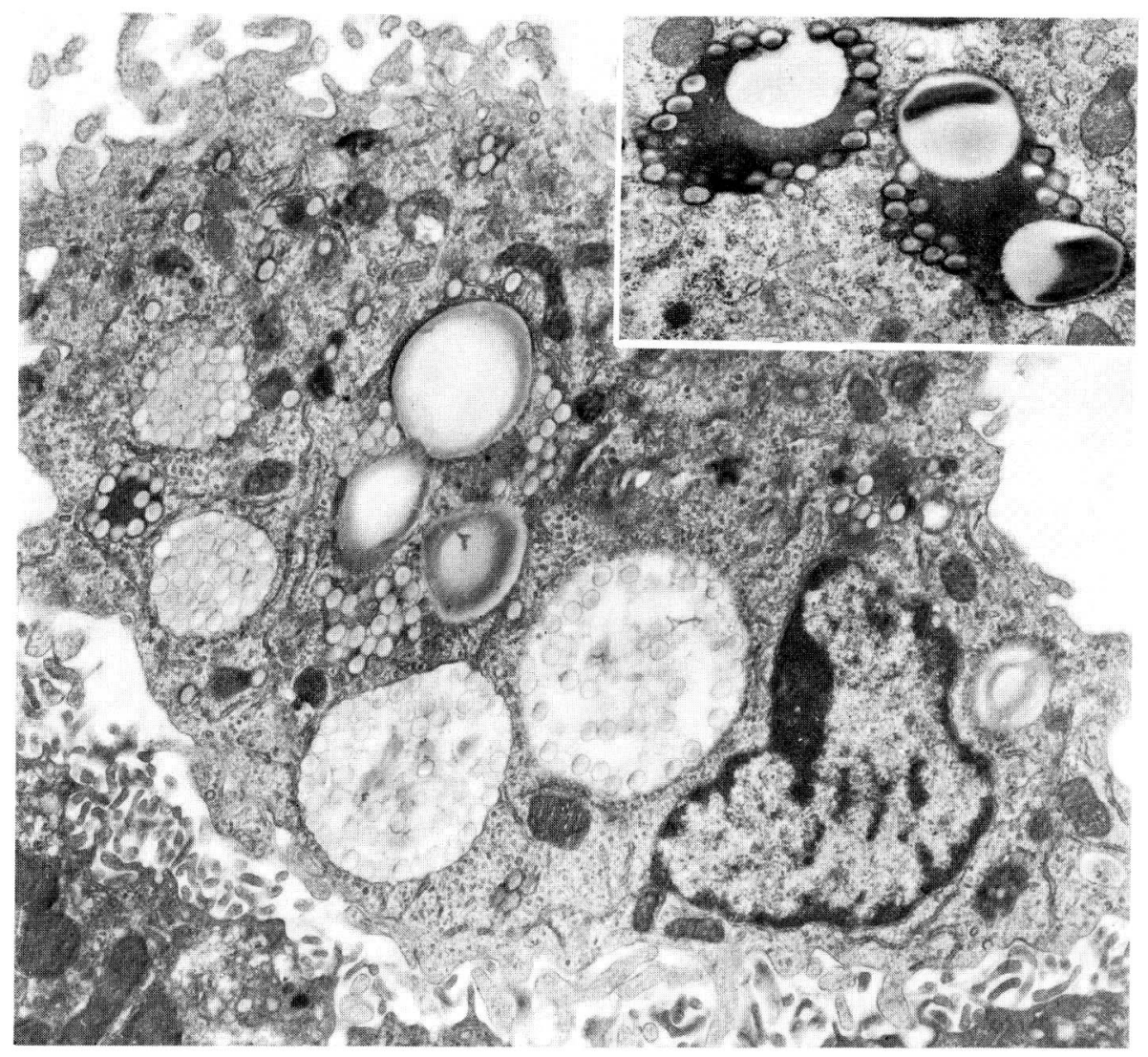

Fig. 1. A Kupffer cell, 2 days after the last of the 3-day series intravenous injections of latex particles. Both small $(0.2 \mu \mathrm{m})$ and large $(2.0 \mu \mathrm{m})$ latex particles taken up are stored in vesicles and vacuoles in the cytoplasm. Some particles are contained in dense bodies. $\times 9,000$. Inset: Latex particles $(0.2$ and $2.0 \mu \mathrm{m}$ in diameter $)$ contained in lysosomes. $\quad \times 12,000$ 


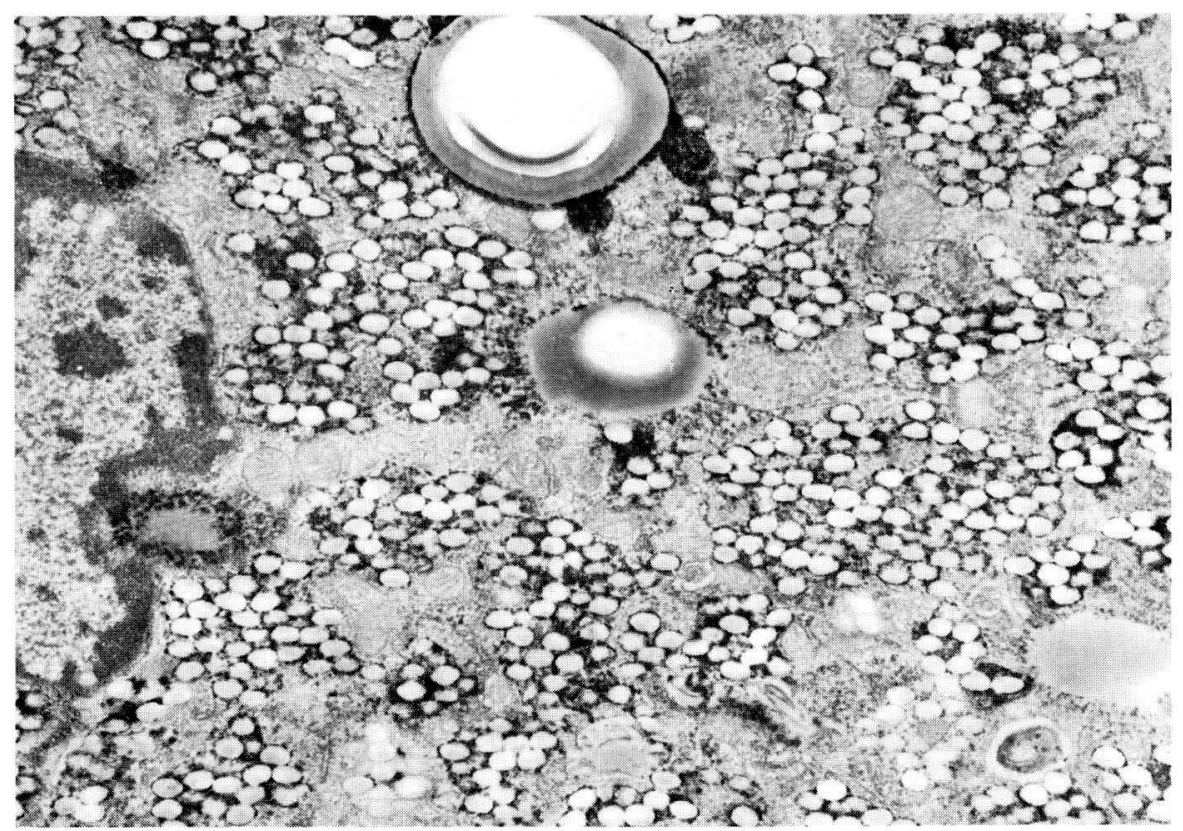

Fig. 2. A part of a Kupffer cell showing AcPase activity in the vacuoles containing latex particles, 4 months after the injection of particles. Most of the cytoplasm is occupied with vacuoles cotaining latex particles. Reaction products for AcPase are localized among the particles in the vacuoles. $\times 10,500$

clusters in the sinusoidal lining, perisinusoidal space (Disse spaces), interlobular connective tissue space, and subperitoneal connective tissue space in the animals 2 days after the injection of latex particles. With time, these clusters became larger in size after the injection. One month after the injection, large clumps of aggregating cells were located in the Disse's spaces and interstitial connective tissue spaces. These clumps could be called granuloma (Fig. 3 ). The largest ones, appearing 3-8 months after injection, were about $80-120 \mu \mathrm{m}$ in diameter and consisted of about 40 cells in a thin section. Cell clusters found in the animals 3 days after the injection of latex particles and large granulomas distributed throughout the liver of the animals 1-8 months after the injection were composed of several kinds of cells: i) Kupffer cells positive for peroxidase activity in the nuclear envelope, cisternae of rough endoplasmic reticulum and of the Golgi apparatus (Fig. 4a); ii) monocytes positive for peroxidase activity only in the cytoplasmic granules (Fig. 4b, 5a); iii) intermediate cells which were positive for peroxidase in the nuclear envelope, cisternae of rough endoplasmic reticulum, and cytoplasmic granules (Fig. 4b, 5b); iv) Kupffer cell-like cells taking up numerous particles but negative for peroxidase activity; v) granulocytes; and vi) plasma cells. The latter two were rarely seen in the peripheral area of the granuloma.

Some cells containing numerous latex particles in the cytoplasm were negative to this reaction, while others also having a large number of the latex particles were positive in the nuclear envelope, cisternae of the rough endoplasmic reticulum, and Golgi apparatus. However, cells having numerous latex particles and showing positive reaction for peroxidase in the cytoplasmic granules were hardly encountered. Though most cells having a single nucleus were in contact with one another showing a distance of about $150 \mathrm{~A}$ in the granuloma, multinucleate giant cells having 2-4 nuclei and 


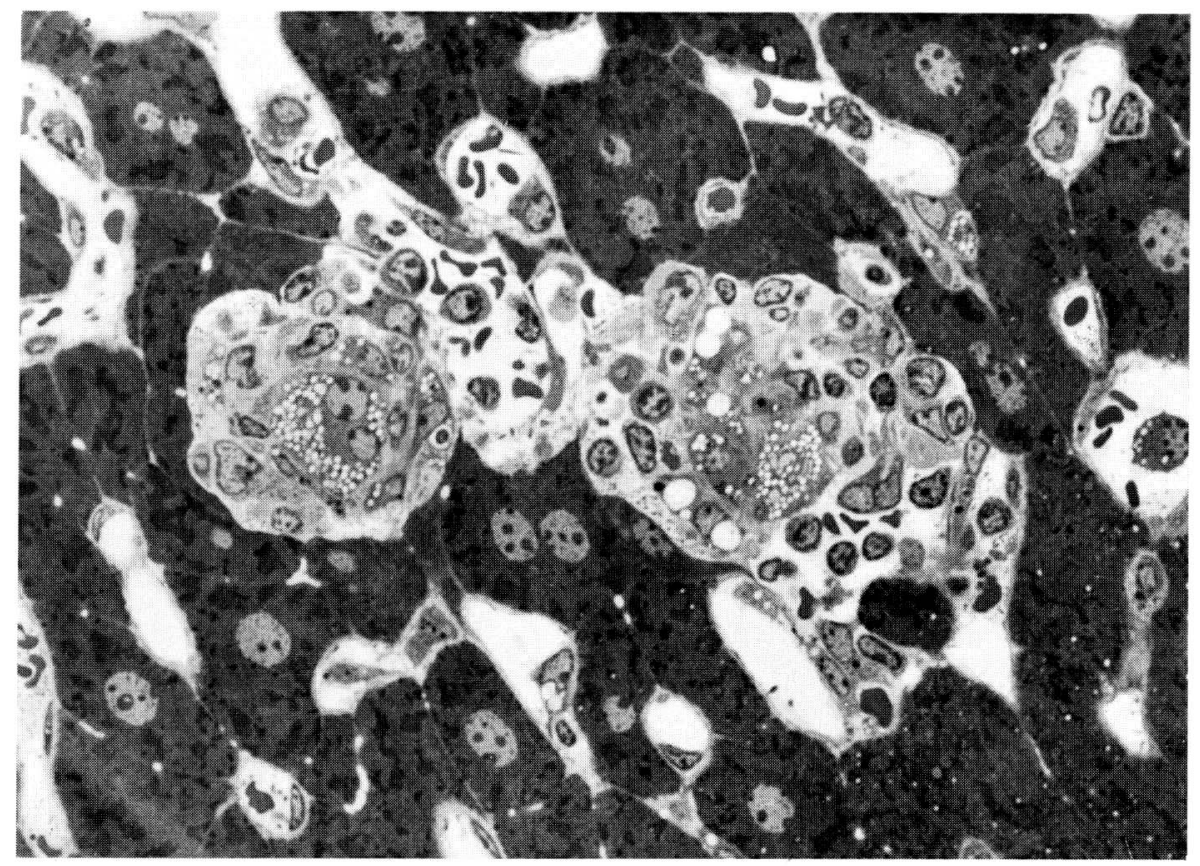

Fig. 3. Light micrograph of granulomas in the liver, 1 month after the injection of latex particles. The granulomas are composed of numerous cells. Kupffer cells laden with latex particles have gathered in the granulomas, while mononuclear cells lacking latex particles are also seen. $\times 400$

numerous latex particles were rarely seen. Interdigitations were sometimes noted among these cells, but no desmosomes were detected.

In the animals receiving ${ }^{3} \mathrm{H}$-thymidine every $8 \mathrm{hr}$ a total of 10 times from the 2 nd day of the injection of latex particles, $34 \pm 4.7 \%$ (average \pm standard deviation) of Kupffer cells with the latex particles (Fig. 6), $7 \pm 2.6 \%$ of sinusoidal endothelial cells, and $0.5 \pm 0.7 \%$ of hepatocytes were labeled. Mitotic Kupffer cells labeled with the radioisotope were occasionally recognized. In addition, the nuclei of some monocytes in the sinusoidal capillary also showed silver grains. A few epithelial cells of the Hering duct were also labeled in their nuclei.

Most granuloma cells stuffed with numerous latex particles in the animals 2-8 months after the latex injection were not labeled by ${ }^{3} \mathrm{H}$-thymidine injected a total of 10 times every $8 \mathrm{hr}$.

Sinusoidal endothelial cells, attenuated in shape and showing long cytoplasmic processes, were also active in taking up the small latex particles, though the number of the particles was very small as compared with that in the Kupffer cell. The particles, $0.2 \mu \mathrm{m}$ in diameter were ingested in the endothelial cell by pinocytosis $3 \mathrm{hr}$ after the injection, and most of them were enclosed singly by a limiting membrane (Fig. 7a). In addition, a few large particles $(2.0 \mu \mathrm{m}$ in diameter) were occasionally taken up (Fig. $7 \mathrm{~b})$. These particles were seen in a few endothelial cells 1 month after injection. The peroxidase activity was strongly positive in the nuclear envelope, and the cisternae of rough endoplasmic reticulum and the Golgi apparatus in a few endothelial cells (Fig. 7a). 


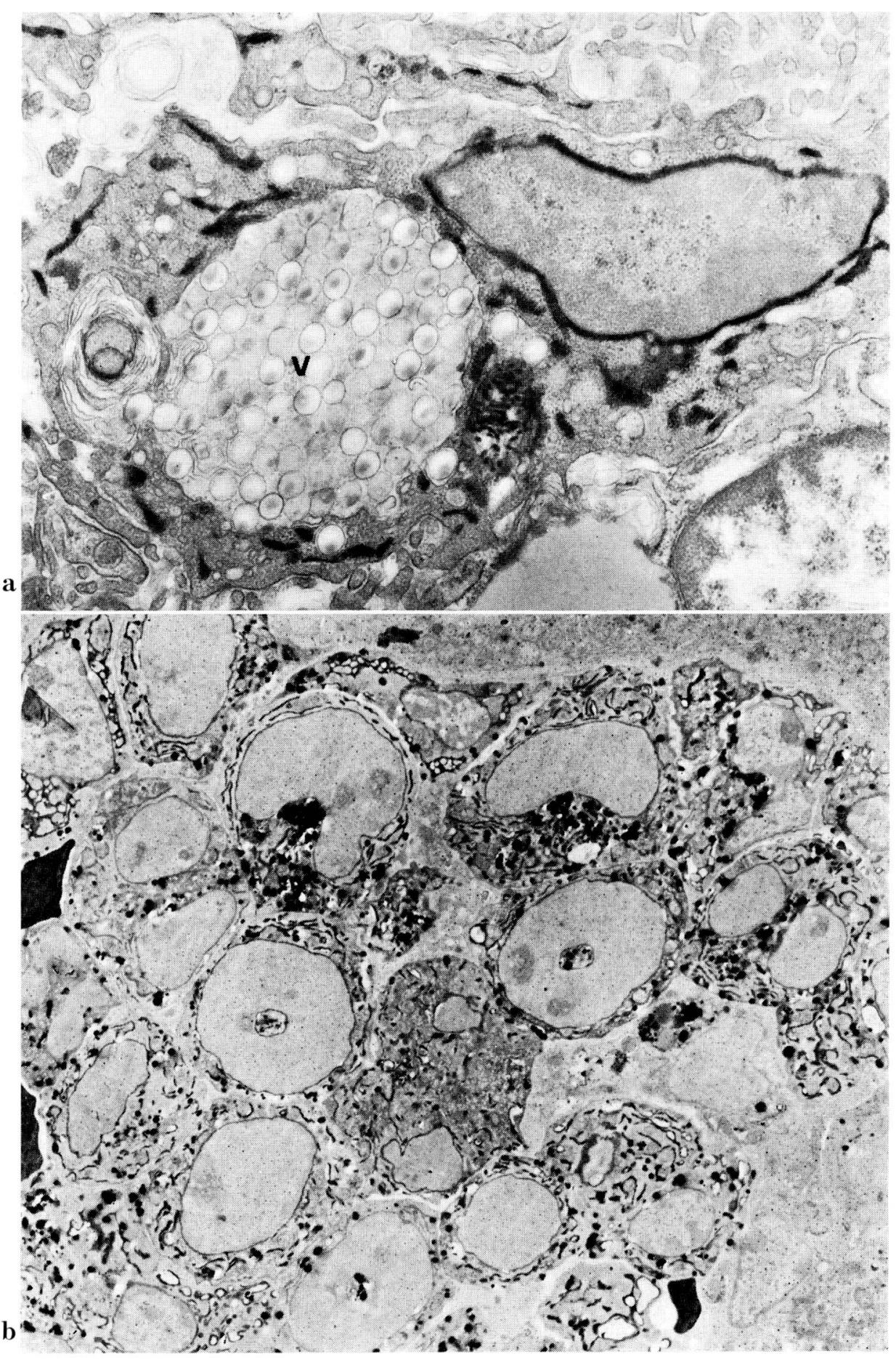

Fig. 4. Legend on the opposite page. 

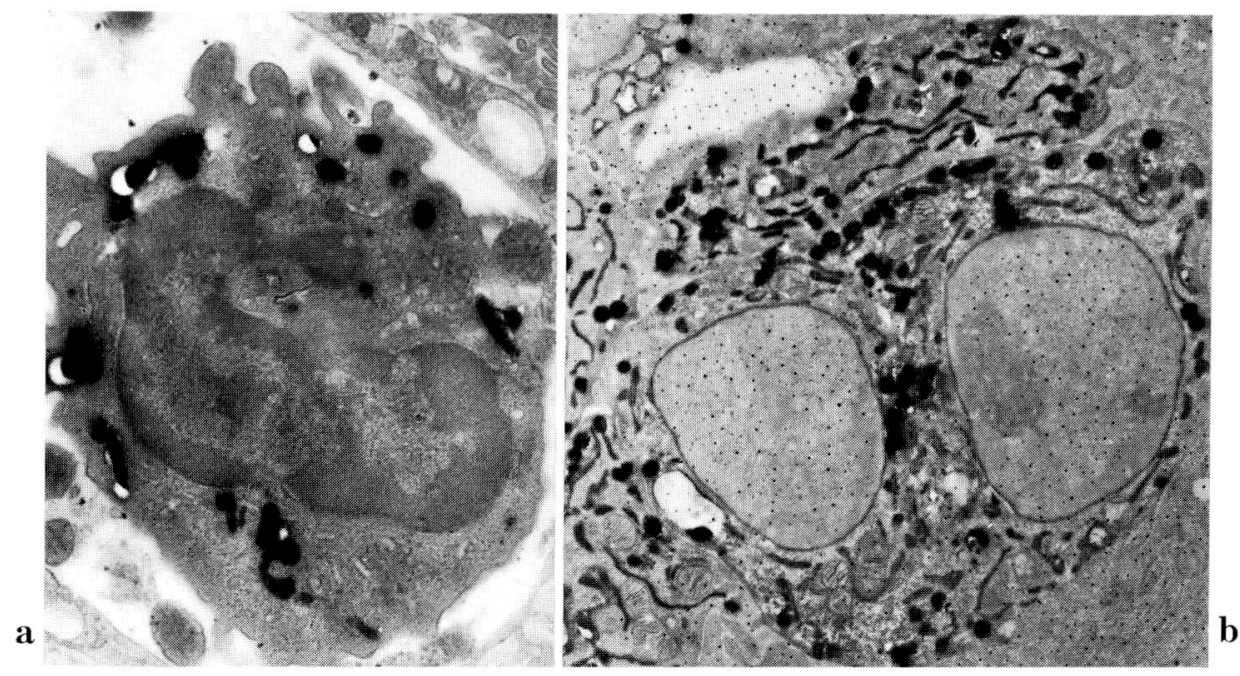

Fig. 5. Peroxidase activity in a monocyte and intermediate cell. a. Monocyte, 3 months after the injection of latex particles. The enzyme activity is localized only in cytoplasmic granules. $\times 9,000$. b. Intermediate cell, 3 months after the injection of latex particles. Peroxidase is positive in cytoplasmic granules, and weakly positive in the nuclear envelope and cisternae of rough endoplasmic reticulum. $\quad \times 5,500$

\section{DISCUSSION}

The latex particles ingested by Kupffer cells tend to accumulate in the lysosomal region. From a few days to several months after the injection, the particles are localized in the secondary lysosomes. While the latex particles in the lysosomes are negative for the acid phosphatase activity, the lysosomal matrices surrounding the particles are strongly positive for this enzyme. In some Kupffer cells, the lysosomal vacuoles containing numerous latex particles occupy most of the cytoplasm. These findings indicate that the lysosomes have a tendency to fuse with the small phagosomes having latex particles, though the lysosomal enzymes can not digest these particles. These phagolysosomes are regarded to be specific residual bodies made by the latex particles and primary lysosomes.

One to eight months after the injection of latex particles, numerous granulomas appeared in the Disse's spaces, as well as the interlobular and subperitoneal connective tissue spaces. The granuloma was formed by the accumulation of Kupffer cells storing latex particles, monocytes and other cells. These facts suggest that the Kupffer cells have the motility as reported by PARRY $(1978 \mathrm{a}, \mathrm{b})$ in $\mathrm{CCl}_{4}$-treated mice. The formation of granulomas in the liver was reported by Deimann and Fahimi (1980a, b) in glucan

Fig. 4. Localization of peroxidase activity. a. A Kupffer cell, 2 days after the last of the 3-day series of injections of latex particles. The peroxidase activity is positive in the nuclear envelope, and cisternae of rough endoplasmic reticulum. A large vacuole $(V)$ containing numerous latex particles is seen. $\times 17,000$. b. Peroxidase activity in a granuloma 3 months after injection of latex particles. Kupffer cells (peroxidase activity is localized in the nuclear envelope and rough endoplasmic reticulum), monocytes (peroxidase activity is localized in cytoplasmic granules), and intermediate cells (peroxidase activity is localized in cytoplasmic granules, nuclear envelope, and rough endoplasmic reticulum) are seen. $\times 3,000$ 


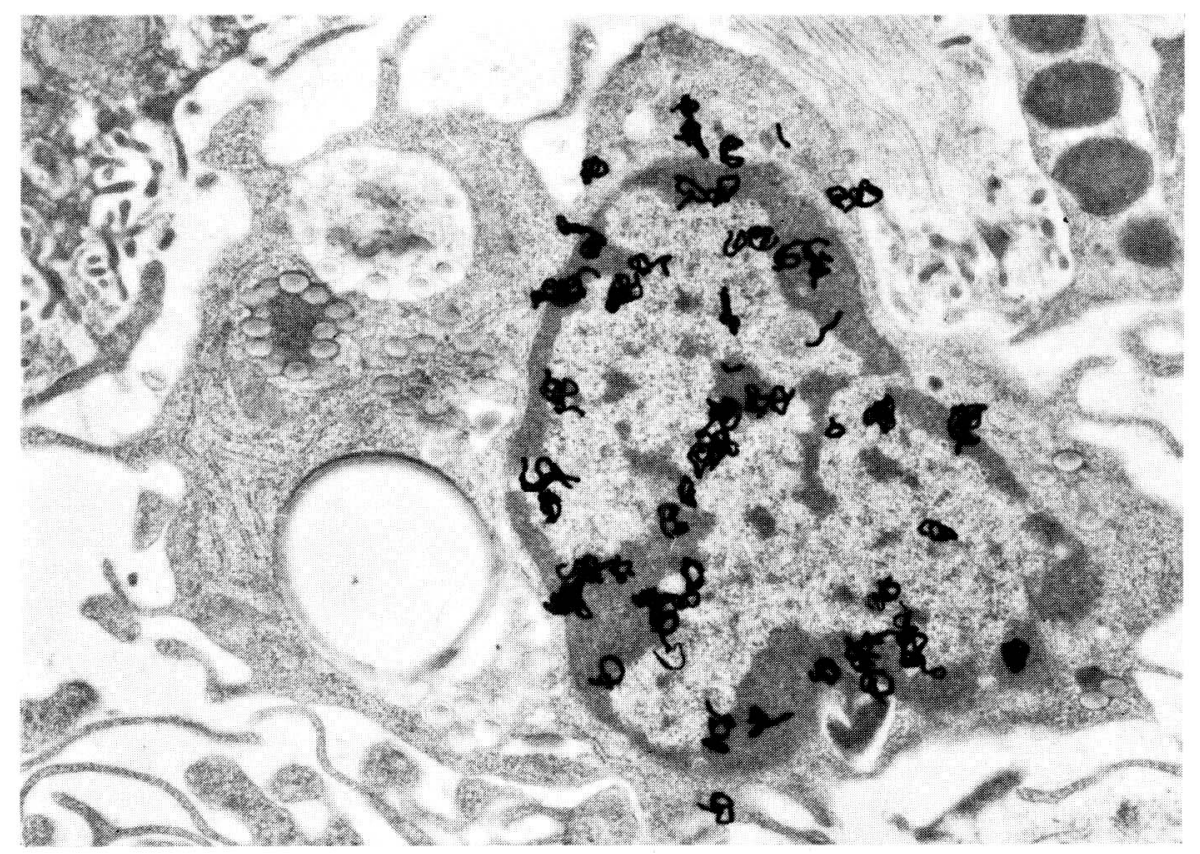

Fig. 6. A Kupffer cell in the liver sinusoid, 2 days after the last injection of latex particles (3-days series) and ${ }^{3} \mathrm{H}$-thymidine. The cell taking up the latex particles is labeled with ${ }^{3} \mathrm{H}$-thymidine. Large $(2.0 \mu \mathrm{m})$ as well as small $(0.2 \mu \mathrm{m})$ latex particles are seen in vacuoles and dense bodies. $\times 11,000$

( $\beta-1,3$-polyglucose)-treated rats, by FuJITA et al. (1983) in Indian ink-treated mice, by W ISSE (1974b) in Thorotrast- or Zymosan-treated rats, and by Hardonk et al. (1982) in particulate alkaline phosphatase-treated rats. Granuloma formation was also reported in the subcutaneous tissue of Melinex plastic-treated rats (VAN DER RHEE et al., 1979).

The granuloma consists of several kinds of cells, such as Kupffer cells, monocytes, granulocytes, and plasma cells. The typical Kupffer cells which take up numerous latex particles show peroxidase activity in the nuclear envelope, cisternae of the rough endoplasmic reticulum and of the Golgi apparatus, while the multinucleate giant cells with numerous latex particles are negative for this enzyme. The monocytes, which are known to be positive for this enzyme only in the cytoplasmic granules, do not store any latex particles. In addition, there are some cells which show a positive reaction for this enzyme in the nuclear envelope, cisternae of the rough endoplasmic reticulum and of the Golgi apparatus, and also in the cytoplasmic granules. This type of cell is considered to be a transitional intermediate cell between the monocyte and Kupffer cell, because the cytoorganelles as well as granules have a peroxidase activity. This type of cell was seen in cultured monocytes (Bodel et al., 1977; Deimann and Fahimi, 1980a) and in the liver treated with glucan (Deimann and Fahimi, 1979). Deimann and Fahimi (1980a, b) showed that glucan, a stimulant of mononuclear phagocytes, induces hemopoiesis in the liver; they referred to the possibility that hepatic macrophages might differentiate from the hematopoietic cells. VAN DER RHEE et al. (1979), reported that monocytes, which are adherent to Melinex implanted in the subcutaneous tissue and differentiate in vivo into macrophages, epitheloid cells and multinucleate giant cells, do not acquire the peroxidase activity in the cisternae of rough endoplasmic reticulum 

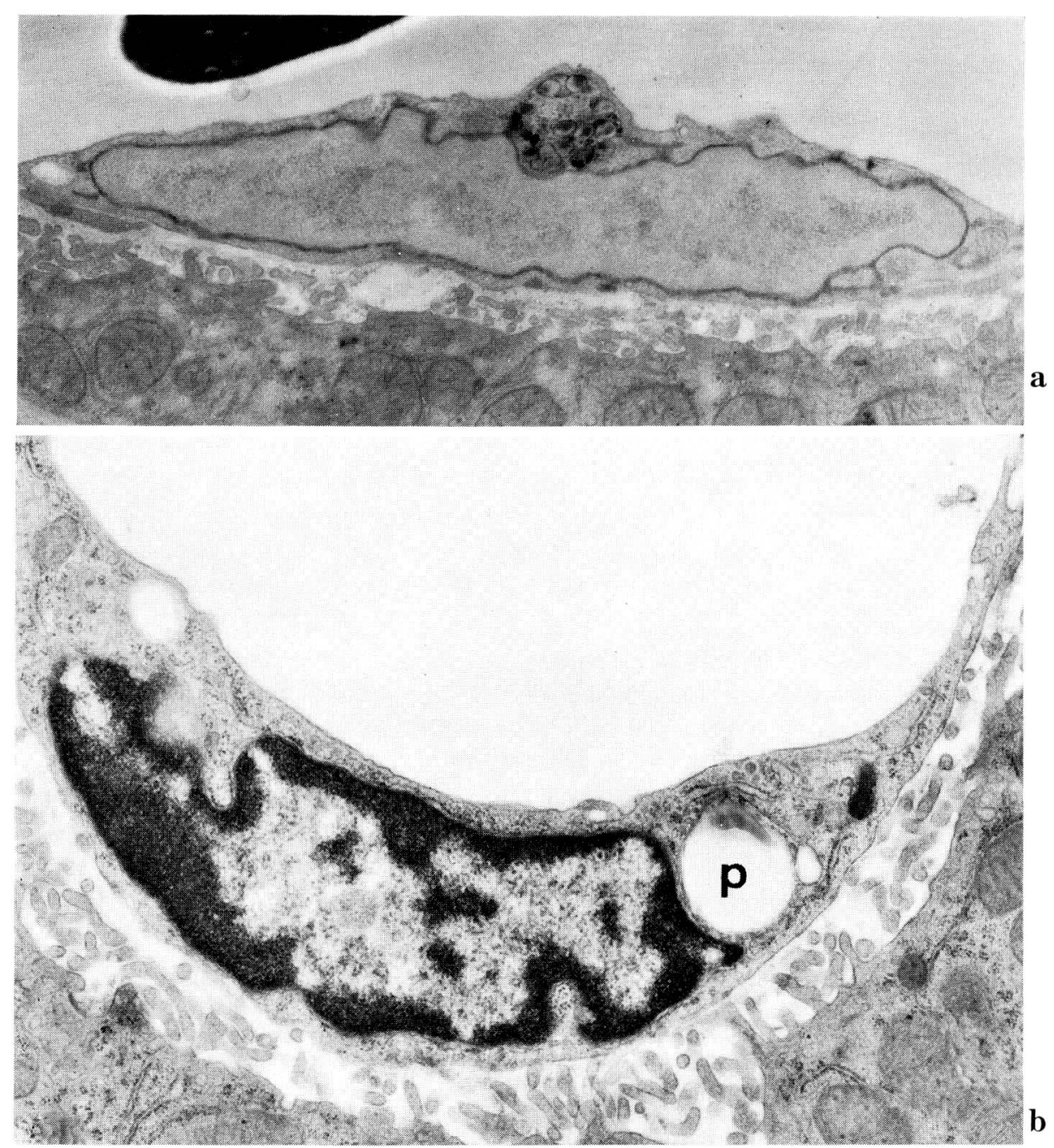

Fig. 7. Sinusoidal endothelial cells. a. A part of an endothelial cell positive for peroxidase activity in the nuclear envelope and cisternae of rough endoplasmic reticulum has a vacuole containing small $(0.2 \mu \mathrm{m})$ latex particles. Three months after the injection of latex particles. $\times 11,000$. b. A part of an endothelial cell, taking up a large $(2.0$ $\mu \mathrm{m})$ latex particle $(P)$. One month after the injection of latex particles. $\times 15,000$

or the nuclear envelope during differentiation. BoDEL et al. (1977) demonstrated that the cultured monocyte adhering to the plastic culture dish develops a peroxidase activity in the cisternae of rough endoplasmic reticulum and nuclear envelope within $2 \mathrm{hr}$. This begins to diminish at $18 \mathrm{hr}$, and by $3-4$ days most cells become peroxidasenegative. This enzymatic activity in these cells does not seem to be constant, but changeable according to their functional state.

With respect to the origin of the macrophage, the notion of the mononuclear phagocyte system was put forth by van Furth (VAN Furth, 1970; van Furth et al., 1972), i.e., the macrophage is recruited from the monocyte in the bone marrow. While we agree with the opinion that the Kupffer cell, one of the macrophages, also derives 
from the bone marrow (VAN FURTh et al., 1977; VAN FURTH, 1980), it is also a fact that a Kupffer cell labeled with ${ }^{3} \mathrm{H}$-thymidine can proliferate in the liver tissue as VolkmanN (1976), Wisse (1974b, 1980), and Deimann and Fahimi (1978) pointed out. Pulford and Sounami (1980) found mitoses in cultured Kupffer cells, and 33\% of the cells underwent DNA synthesis in a $24 \mathrm{hr}$ period. As to the origin of Kupffer cells, Bouwens and WISsE (1982) suggested a dual mechanism of intrahepatic proliferation and recruitment from extrahepatic sources during a zymosan-induced acute inflammation. VAN FURTH and BLussé (1982) also considered the possibility that Kupffer cells were self-renewing as well as recruited from monocytes. In the normal steady state, the maintenance of the Kupffer cell population depends mainly on the influx of circulating bone marrowproduced monocytes transforming into Kupffer cells, and only to a minor degree on local division of mononuclear phagocytes.

NoRTH (1969) reported that mice which had been first injected with carbon and then treated with Listeria monocytogenes showed many carbon-containing Kupffer cells in mitosis or incorporating ${ }^{3} \mathrm{H}$-thymidine in the nuclei, but carbon-containing cells failed to be labeled unless the liver was infected with L. monocytogenes, and the local proliferation was caused by the infection. In the present study, we had reason to consider that the ingested latex particles were adequate stimuli for the incorporation of ${ }^{3} \mathrm{H}$-thymidine into the Kupffer cell.

It is of interest that the liver sinusoidal endothelial cell also has an endocytotic activity for latex particles. WIDMANN and FAHIMI (1975) reported that latex particles larger than $0.8 \mu \mathrm{m}$ in diameter were never taken up by the sinusoidal endothelial cells of the liver, but in our study large particles, $2.0 \mu \mathrm{m}$ in diameter could be taken up into this type of cell, though not so often, in addition to smaller particles of $0.2 \mu \mathrm{m}$ in diameter. We wish to emphasize that the hepatic sinusoidal endothelial cell is also involved in cleaning up the blood stream as TAMARU and FujiTA (1978) and Fujita et al. (1983) reported, though this type of cell essentially differs from the Kupffer cell in morphology (Wisse, 1972, 1974a, 1977; MotтA, 1975; Muto, 1977; Muto et al., 1977) and in the grade of endocytotic activity (WIDMANN and FAHIMI, 1975). It is well known that the Kupffer cell characteristically shows peroxidase activity in the cisternae of its rough endoplasmic reticulum and nuclear envelope (FAHImI, 1970; WIDMANN et al., 1972; WISSE, 1974a). In the present paper, a few sinusoidal endothelial cells showed such peroxidase activity in the nuclear envelope, and cisternae of rough endoplasmic reticulum, similar to Kupffer cells. Similar findings have been reported by STöHR et al. (1978) and Litwin (1984). This fact means that the localization of peroxidase in the cell is not always absolute for identification of the Kupffer cell from other types of cells. STöHR et al. (1978) reported that the peroxidase activity is localized in the rough endoplasmic reticulum and nuclear envelope in more than one half of all the endothelial cells of the mouse liver, and pointed out that peroxidase staining, as a marker for identification of Kupffer cells, is only of limited value and should be used in conjunction with other methods.

The Kupffer cells ingesting numerous latex particles gather in the connective tissue space and remain there, making a granuloma, for a considerable time. The formation of the granuloma and clump of Kupffer cells in the interlobular or subperitoneal connective tissue space is considered to play a great role in the disposing of foreign materials from the functional parenchymatous liver tissue. This might be a vital reaction in protecting the parenchymatous tissue from undigested foreign materials in order for it to perform the liver function. As Fujita et al. (1983) reported, Kupffer cells in the clump and granuloma are unlikely to be soon replaced, and live 
for a long period (perhaps until their death) in the liver, though the possibility that the latex particles in these cells are transferred to newly formed Kupffer cells could not be excluded.

\section{REFERENCES}

Bodel, P. T., B. A. Nichols and D. F. Bainton: Appearance of peroxidase reactivity within the rough endoplasmic reticulum of blood monocytes after surface adherence. J. exp. Med. 145: 264-274 (1977).

Bouwens, L. and E. Wisse: On the dual origin of the Kupffer cells. In: (ed. by) D. L. Knook and E. Wisse: Sinusoidal liver cells. Elsevier, Amsterdam, 1982 (p. 165-172).

Deimann, W. and H. D. Fahimi : Peroxidase cytochemistry and ultrastructure of resident macrophages in fetal rat liver: A developemental study. Devel. Biol. 66: 43-56 (1978).

: The appearance of transition forms between monocytes and Kupffer cells in the liver of rats treated with glucan: A cytochemical and ultrastructural study. J. exp. Med. 149: 883-897 (1979).

tivator. A cytochemical and ultrastructural study. Lab. Invest. 42: 217-224 (1980a).

- : Hepatic granulomas induced by glucan: An ultrastructural and peroxidase-cytochemical study. Lab. Invest. 43: 172-181 (1980b).

Fahimi, H. D.: The fine structural localization of endogenous and exogenous peroxidase activity in Kupffer cells of rat liver. J. Cell Biol. 47: 247-262 (1970).

Fujita H., S. Kawamata and K. Yamashita: Electron microscopic studies on multinucleate foreign body giant cells derived from Kupffer cells in mice given Indian ink intravenously. Virchows Arch. (Cell Pathol.) 42: 33-42 (1983).

Gomori, G.: Microscopic histochemsitry III. The University of Chicago Press, Chicago, 1952 (p. 193).

Graham, R. C., Jr. and M. J. Karnovsky: The early stages of absorption of injected horseradish peroxidase in the proximal tubules of mouse kidney: Ultrastructural cytochemistry by a new technique. J. Histochem. Cytochem. 14: 291-302 (1966).

Hardonk, M. J., F. W. J. Dijkhuis, A. Feringa, J. Koudstaal : The development of granulomas in rat liver after i.v. injection of particulate pig intestinal alkaline phosphatase. In: (ed. by) D. L. Knook and E. Wisse: Sinusoidal liver cells. Elsevier, Amsterdam, 1982 (p. 185-192).

Litwin, J. A.: Peroxidase-positive endothelial cells in rat liver. Cell Tiss. Res. 238: 635-642 (1984).

Motta, P.: A scanning electron microscopic study of the rat liver sinusoid. Endothelial and Kupffer cells. Cell Tiss. Res. 164: 371-385 (1975).

Muto, M.: A scanning electron microscopic study on endothelial cells and Kupffer cells in rat liver sinusoids. Arch. histol. jap. 37: 369-386 (1975).

Muto, M., M. Nishi and T. Fujita : Scanning electron microscopy of human liver sinusoids. Arch. histol. jap. 40: 137-151 (1977).

North, R. J.: The mitotic potential of fixed phagocytes in the liver as revealed during the development of cellular immunity. J. exp. Med. 130: 315-326 (1969).

Novikoff, A. B.: Lysosomes in the physiology and pathology of cells: Contribution of staining methods. In: (ed. by) A. V. S. de Reuck and M. P. Cameron: Ciba Foundation symposium in lysosomes. Little, Brown Co., Boston, 1963 (p. 36-73).

Parry, E. W. : Studies on mobilization of Kupffer cells in mice. I. The effect of carbon tetrachlorideinduced liver necrosis. II. Mobilization mediated by necrotic tissue injected intraperitoneally. J. comp. Pathol. 88: 481-487, 489-495 (1978a, b).

Pulford, K. and R. L. Souhami : Cell division and giant cell formation in Kupffer cell cultures. Clin. exp. Immunol. 42: 67-76 (1980).

Stöhr, G., W. Deimann and H. D. Fahimi : Peroxidase-positive endothelial cells in sinusoids of the mouse liver. J. Histochem. Cytochem. 26: 409-411 (1978). 
Tamaru, T. and H. Fujita : Electron-microscopic studies on Kupffer's stellate cells and sinusoidal endothelial cells in the liver of normal and experimental rabbits. Anat. Embryol. 154: 125-142 (1978).

Van der Rhee, H. J., C. P. M. van der Burgh-de Winter and W. Th. Daems: The differentiation of monocytes into macrophages, epitheloid cells and multinucleated giant cells in subcutaneous granulomas. I. Fine structure. Cell Tiss. Res. 197: 355-378 (1979).

van Furth, R.: The origin and turnover of promonocytes, monocytes and macrophages in normal mice. In: (ed. by) R. van Furth: Mononuclear phagocytes. Blackwell Sci., Oxford, 1970, (p. 151165).

-: Monocyte origin of Kupffer cells. Blood Cells 6: 87-90 (1980).

van Furth, R. and D. Blussé van Oud Alblas: New aspects on the origin of Kupffer cells. In: (ed. by) D. L. Knook and E. Wisse: Sinusoidal liver cells. Elsevier, Amsterdam, 1982 (p. 173-183).

van Furth, R., Z. A. Cohn, J. G. Hirsch, J. H. Humphrey, W. G. Spector and H. L. Langevoort: The mononuclear phagocyte system: A new classification of macrophages, monocytes, and their precursor cells. Bull. WHO 46: 845-852 (1972).

van Furth, R., R. W. Crofton and M. M. C. Diesselhoff-den Dulk: The bone marrow origin of Kupffer cells. In: (ed. by) E. Wisse and D. L. Knook: Kupffer cells and other liver sinusoidal cells. Elsevier/North-Holland Biomedical Press, Amsterdam, 1977 (p. 471-480).

Volkmann, A.: Disparity in origin of mononuclear phagocyte populations. J. Reticuloendothel. Soc. 19: 249-268 (1976).

Widmann, J.-J. and H. D. Fahimi : Proliferation of mononuclear phagocytes (Kupffer cells) and endothelial cells in regenerating rat liver. Amer. J. Pathol. 80: 349-366 (1975).

Widmann, J.-J., R. S. Cotran and H. D. Fahimi: Mononuclear phagocytes (Kupffer cells) and endothelial cells. Identification of two functional cell types in rat liver sinusoids by endogenous peroxidase activity. J. Cell Biol. 52: 159-170 (1972).

Wisse, E.: An ultrastructural characterization of the endothelial cell in the rat liver sinusoid under normal and various experimental conditions, as a contribution to the distinction between endothelial and Kupffer cells. J. Ultrastr. Res. 38: 528-562 (1972).

-: Observation on the fine structure and peroxidase cytochemistry of normal rat liver Kupffer cells. J. Ultrastr. Res. 46: 393-426 (1974a).

-: Kupffer cell reactions in rat liver under various conditions as observed in the electron microscope. J. Ultrastr. Res. 46: 499-520 (1974b).

-: Ultrastructure and function of Kupffer cells and other sinusoidal cells. In: (ed. by) E.Wisse and D. L. Knook: Kupffer cells and other liver sinusoidal cells. Elsevier/North-Holland, Amsterdam, 1977 (p. 33-60).

-: On the Kupffer cell origin of Kupffer cells. Blood Cells 6: 91-92 (1980).

藤田尚男

于530 大阪市北区中之島 4-3-57

大阪大学医学部

第三解剖学教室
Prof. Hisao Fujita

Department of Anatomy

Osaka University School of Medicine

Nakanoshima 4-3-57, Kitaku

Osaka, 530 Japan 